\title{
Clinical Characteristics of Patients Diagnosed with Odontogenic Maxillary Sinusitis through the Consultation with Dentistry
}

\author{
Sangjun Kim ${ }^{(\mathbb{D}}$, Daeyeon Kim ${ }^{\mathbb{D}}$, Sang Hoo Park ${ }^{\mathbb{D}}$, and Woo Yong Bae \\ Department of Otorhinolaryngology-Head and Neck Surgery, Dong-A University College of Medicine, Busan, Korea
}

\section{치과 협진에 의해 치성 부비동염으로 진단된 환자들의 임상적 특징에 대한 고찰}

김상준 · 김대연 · 박상후 · 배우용

동아대학교 의과대학 이비인후-두경부외과학교실

Received November 8, 2019

Revised February 7, 2020

Accepted February 12, 2020

Address for correspondence

Woo Yong Bae, MD, PhD

Department of Otorhinolaryngology-

Head and Neck Surgery,

Dong-A University

College of Medicine,

26 Daesingongwon-ro, Seo-gu,

Busan 49201, Korea

Tel $+82-51-240-5428$

Fax $+82-51-253-0712$

E-maildoncamel@dau.ac.kr
Background and Objectives For maxillary sinus diseases, it is not easily determined whether it is of the sinus or dental origin as the root of a tooth is located in the maxillary sinus; hence the need to find the pathologic origin for better clinical results. The purpose of this study was to define the characteristics of patients who had needed to consult both a dentist and an otolaryngologist with respect to the diagnosis and management.

Subjects and Method Thirty-one patients who visited the department of dentistry and ENT between 2014 and 2018 were included in the study. Patients with dental implant sinusitis were excluded. We restrospectively reviewed the medical records for chief complaints, assessment, diagnose, treatment, and prognosis of the patients.

Results Of 31 patients, 13 patients were diagnosed with odontogenic rhinosinusitis (ORS), 5 with postoperative cheek cyst (POCC), 2 with radicular cyst without ORS, 7 with sinusitis, and 4 with other diseases. Thirteen patients underwent combined operation and 5 at each department. Follow-up periods was about 6.5 months. There was no disease recurrence except one patients with POCC.

Conclusion There needs to be an active consultation with the dentistry department in case of unilateral sinusitis and past history of dental treatment temporally or when patients show positive findings in $\mathrm{CT}$. Korean J Otorhinolaryngol-Head Neck Surg 2020;63(6):259-64

Key Words Diagnosis $\cdot$ Maxillary disease $\cdot$ Odontogenic sinusitis.

\section{서 론}

상악동에 발생하는 질병은 주로 비강에서 기원하지만 일부 는 치성 원인 질환의 상악동 침범에 의해서도 발생할 수 있다. 그 이유는 해부학적으로 구강과 상악동은 맞닿아 있으며, 서 로 영향을 줄 수 있는 구조이기 때문이다.,2)

전체 상악동염의 10 40\% 정도는 치성 부비동염인 것으로

This is an Open Access article distributed under the terms of the Creative Commons Attribution Non-Commercial License (https://creativecommons.org/licenses/by-nc/4.0) which permits unrestricted non-commercial use, distribution, and reproduction in any medium, provided the original work is properly cited.
알려져 있으나 실제 진단이나 치료 시 치성 원인을 놓치는 경 우가 많다. ${ }^{3-6)}$ 대부분의 상악동 질환 환자들이 이비인후과를 방문하게 되고 정확한 원인을 찾거나 치료가 잘 되지 않는 경 우 부비동 전산화단층촬영을 시행하게 된다.) 그러나 촬영 결 과를 정확하게 확인하지 않는 경우 치성 원인을 놓쳐 치료 시 기를 놓치거나 결과에 영향을 미칠 수 있으므로 치성 원인이 있는지 찾고 적절히 치과와 협진하는 것이 치료에 중요한 과정 이다.

본 연구는 상악동 질환 환자 중 치과와 협진을 시행하여 치 성 원인을 감별한 환자군들을 조사하여 임상학적 특성을 알 
아보고 앞으로 진단 및 치료 방침을 정하는데 도움이 되고자 시행하였다.

\section{대상 및 방법}

2014 2018년까지 본원 이비인후과와 치과 협진 하에 치료 를 시행한 상악동 질환 환자들 중 임플란트 전후 부비동염 환자들을 제외한 상악동 질환을 가진 환자 31 명을 대상으로 의무 기록을 후향적으로 조사하였다.

이비인후과를 방문한 환자들은 처음 내원하여 주 증상, 치 과 치료 과거력을 물어보았으며, 이학적 검사를 수행하고 전 산화단층촬영을 시행하였다. 상악동염이 있는 환자 중 치성 증상이 있거나, 치과 치료 과거력이 있거나, 전산화단층촬영 상 이상 소견 등의 치성 원인이 의심이 되는 경우 치과와 협 진을 진행하였다.

치과를 방문한 환자들은 이학적 검사상 치아 및 치조골, 치 주의 현재 상태를 진찰하고, panoramic radiography, cone beam $\mathrm{CT}(\mathrm{CBCT})$ 상 상악동 혼탁이 있는 경우 상악동 질환 에 대한 평가를 위해 이비인후과와 협진을 진행하였다.

치성 부비동염에 대한 진단은 전산화단층촬영에서 양성 소 견이 있거나, 문진 상 치성 부비동염을 의심할만한 증상이 있 거나, 치 질환의 병력이 있고 이와 같은 치 질환의 병력이 부비 동염의 증상과 시간적 순서가 맞는 환자를 대상으로 치과와 협진을 의뢰한 환자 중 이학적 검사상 치과적 병변이 확인되 며 이를 뒷받침하는 기록이 남아있는 경우에 치성 부비동염 으로 확진하였다. 전산화단층촬영상의 양성 소견은 상악 치 조골(maxillary alveolar bone)에 결손으로 인한 구강상악동 루(oroantral fistula) 혹은 상악동 내 치아의 함입이나 치아에 영향을 받을 수 있는 구조가 명확히 있는 경우를 양성소견으 로 보았다(Fig. 1).

그 외 다른 상악동 질환은 전산화단층촬영상 의심할만한
소견이 보이며, 치과와 협진 하에 이학적 검사상 치과적 병변 이 확인되는 경우와 이를 뒷받침하는 기록이 남아있는 경우 에 진단하였다.

치성 부비동염으로 진단된 환자들은 항생제 치료와 치과 치료를 받거나 이비인후과 및 치과와 협진하에 수술을 하거 나, 이미 발치가 된 환자들은 내시경적 부비동 수술만 수행하 였다. 그 외 다른 상악동 질환의 환자군들은 각 질환에 맞는 치료를 시행하였다. 모든 환자는 3 개월 이상의 경과 관찰을 시 행하여 재발을 확인하였다.

이 연구는 해당 병원의 임상시험윤리위원회(IRB)의 심의를 거쳐 승인을 받은 후 시행되었다(승인번호: DAUHIRB 19-149).

\section{결 과}

31 명의 환자들 중 남자는 17 명(54\%), 여자 14 명(45\%)이었 으며, 평균 나이는 54(range; 18 85세)였다. 연령별로는 10대 1 명(3\%), 20대 2명(6\%), 30대 5명(16\%), 40대 4(13\%) 50대 7명 (22\%), 60대 6명(19\%), 70대 5명(16\%), 80대 1명(3\%)로 분포 되어 있었다.

이비인후과에서 초진 시행한 환자는 20 명, 치과에서 초진 을 시행한 환자는 11 명이었다. 전산화단층촬영상 양측의 부 비동 혼탁은 3 건(9\%), 편측의 혼탁은 28 건(91\%)으로, 편측의 부비동염이 많았으며, 좌측이 15건(46\%), 우측이 13건(40\%)로 좌우의 차이는 보이지 않았다. 상악동만 파급된 경우 17 건, 상 악동 및 다른 부비동에 파급된 경우 14 건이었으며, 완전 혼탁 은 19건, 부분 혼탁은 12건으로 나타났다.

진단된 환자의 주요 질환은 다음과 같다. 치성 부비동염 (odontogenic rhinosinusitis) 13명, 수술 후 협부낭종(postoperative cheek cyst) 5명, 만성 부비동염(chronic rhinosinusitis) 3명, 진균성 부비동염(fungal sinusitis) 2명, 급성 부 비동염(acute rhinosinusitis) 2명, 치근낭(radicular cyst) 2명,
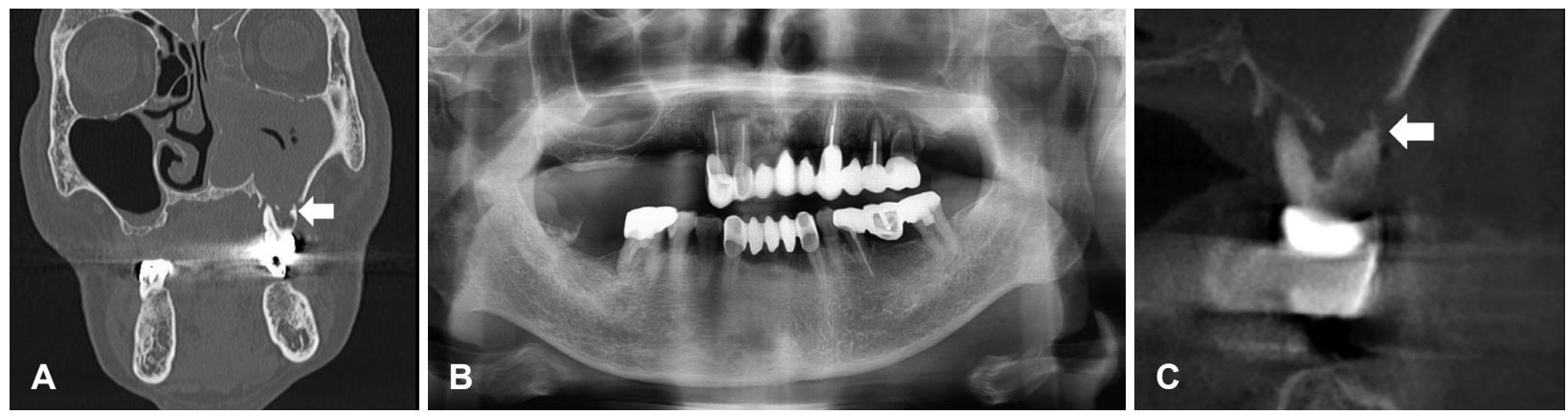

Fig. 1. A case of ORS with positive finding in CT. PNS CT showing total opacity of left maxillary sinus and ethmoidal sinus with oroantral communicating to tooth root (arrow) (A). Panoramic radiography showing left upper 2nd premolar and 1st molar's periodontal ligament space enlargement with infection and floating of tooth root (B). CBCT showing buccal side of left upper 1st molar root infection spreading to left maxillary area (arrow) (C). ORS: odontogenic rhinosinusitis, PNS CT: paranasal sinus computer tomography, CBCT: cone beam computer tomography. 
저류낭종(retension cyst) 1명, 기타 협부 농양(buccal abscess), 상악동 내 이물질, 속 말림 유두종(inverted papilloma)의 치 근단 파급으로 협진 진료한 환자 3명이 있으며, 치료 후 추적 관찰기간의 평균은 6.5 개월이다(Table 1).

이비인후과에서 치성 부비동염 의심 하에 치과와 협진한 환자군의 특성을 분석하였다.

환자가 호소하는 증상 및 치성 과거력에 의한 분석을 한 결과 20명의 환자군 중 치아 증상(치통, 안면통, 악취)만 있는 환자 4명 중 0명(0\%), 발치 5명 중 4명(80\%), 치근단 치료 5명 중 3명 $(60 \%)$, 치주염 4명 중 3명(75\%), 치성 낭종 2명 중 2명 (100\%)이 치성 부비동염으로 진단되었다.

Table 1. Demographic data of 31 patients in 2014-2018 with maxillary sinus disease

\begin{tabular}{|c|c|}
\hline & Maxillary disease $(n=31)$ \\
\hline Mean age (year) & $54(\max =85, \min =18)$ \\
\hline \multicolumn{2}{|l|}{$\operatorname{Sex}(\%)$} \\
\hline Male & $17(54)$ \\
\hline Female & $14(45)$ \\
\hline \multicolumn{2}{|l|}{ Location (\%) } \\
\hline Bilateral & $3(9)$ \\
\hline Left & $15(46)$ \\
\hline Right & $13(40)$ \\
\hline \multicolumn{2}{|l|}{ Opacity (\%) } \\
\hline Total & $19(59)$ \\
\hline Partial & $12(38)$ \\
\hline \multicolumn{2}{|l|}{ Diagnosis (\%) } \\
\hline ORS & $13(40)$ \\
\hline POCC & $5(15)$ \\
\hline Radicular cyst & $2(6)$ \\
\hline Sinusitis (ARS, CRS, fungal sinusitis) & $7(21)$ \\
\hline Etc & $4(15)$ \\
\hline \multicolumn{2}{|l|}{ Recurrence (\%) } \\
\hline No recurrence & $30(96)$ \\
\hline Recurrence & $1(3)$ \\
\hline Mean follow up & 6.51 month $(n=31)$ \\
\hline
\end{tabular}

ORS: odontogenic rhinosinusitis, POCC: postoperative cheek cyst, ARS: acute rhinosinusitis, CRS: chronic rhinosinusitis
이비인후과에서 치성 부비동염 의심 하에 치과와 협진한 환자의 영상 소견을 분석을 한 결과 전산화단층촬영상 치성 상악동 교통(oro-antral communication) 혹은 치근의 상악 동 침범(tooth root invasion)이 있는 환자를 영상학적으로 의미 있는 소견으로 보았으며, 분석 결과 영상의학적으로 양 성인 환자는 20명 중 11 명이었다(Table 2). 두 군 사이에 상악 동의 발생 위치(편측, 양측)나 혼탁의 정도(완전 혼탁, 부분 혼 탁)에서 유의미한 소견은 없었다. 치과 협진 결과 양성인 11 명 중 10 명은 실제 치성 부비동염이 진단되었고(Fig. 1), 음성인 9명 중 3명은 치성 부비동염으로 진단되었으며, 6명은 부비동 염으로 진단되었다.

영상의학적으로 치성 부비동염이 보이지 않던 3건의 환자 는 치과 질환을 않았던 과거력 및 치아의 이학적 검사상 치 근단의 염증 소견이 있어서 진단되었다(Fig. 2).

Table 2. Comparison between radiologic positive finding group and radiologic negative finding group

\begin{tabular}{lcc}
\hline \multicolumn{1}{c}{ Variable } & $\begin{array}{c}\text { Positive } \\
\text { group }(n=11)\end{array}$ & $\begin{array}{c}\text { Negative } \\
\text { group }(n=9)\end{array}$ \\
\hline Age & 60 & 51.7 \\
Dental origin & 0 & 4 \\
Toothache, maxilla pain & 5 & 1 \\
Periodontitis, radicular cyst & 2 & 1 \\
Extraction & 4 & 1 \\
Post-dental procedure & & \\
Location & 9 & 9 \\
Unilateral & 2 & 0 \\
Bilateral & & \\
Opacity & 9 & 4 \\
Total & 2 & 5 \\
Partial & & 3 \\
Diagnosis & 10 & 6 \\
ORS & 1 & \\
Other sinusitis & & \\
\hline
\end{tabular}

Dental procedure: dental procedure like extraction or sinus lifting or scaling. Radiologic positive findings: oroantral communication or dental roots invasion to maxillary sinus. ORS: odontogenic rhinosinusitis
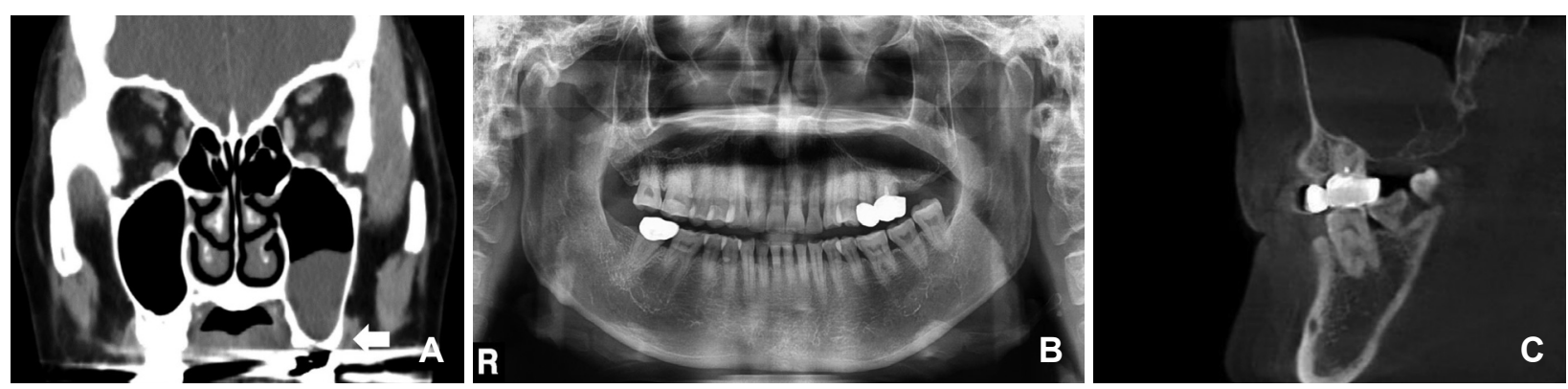

Fig. 2. A case of ORS with negative finding in CT. PNS CT showing partial opacity of left maxillary sinus without oroantral communicating to tooth root (arrow) (A). Panoramic radiography and CBCT showing intact tooth root without soft tissue inflammation (B, C). ORS: odontogenic rhinosinusitis, PNS CT: paranasal sinus computer tomography, CBCT: cone beam computer tomography. 


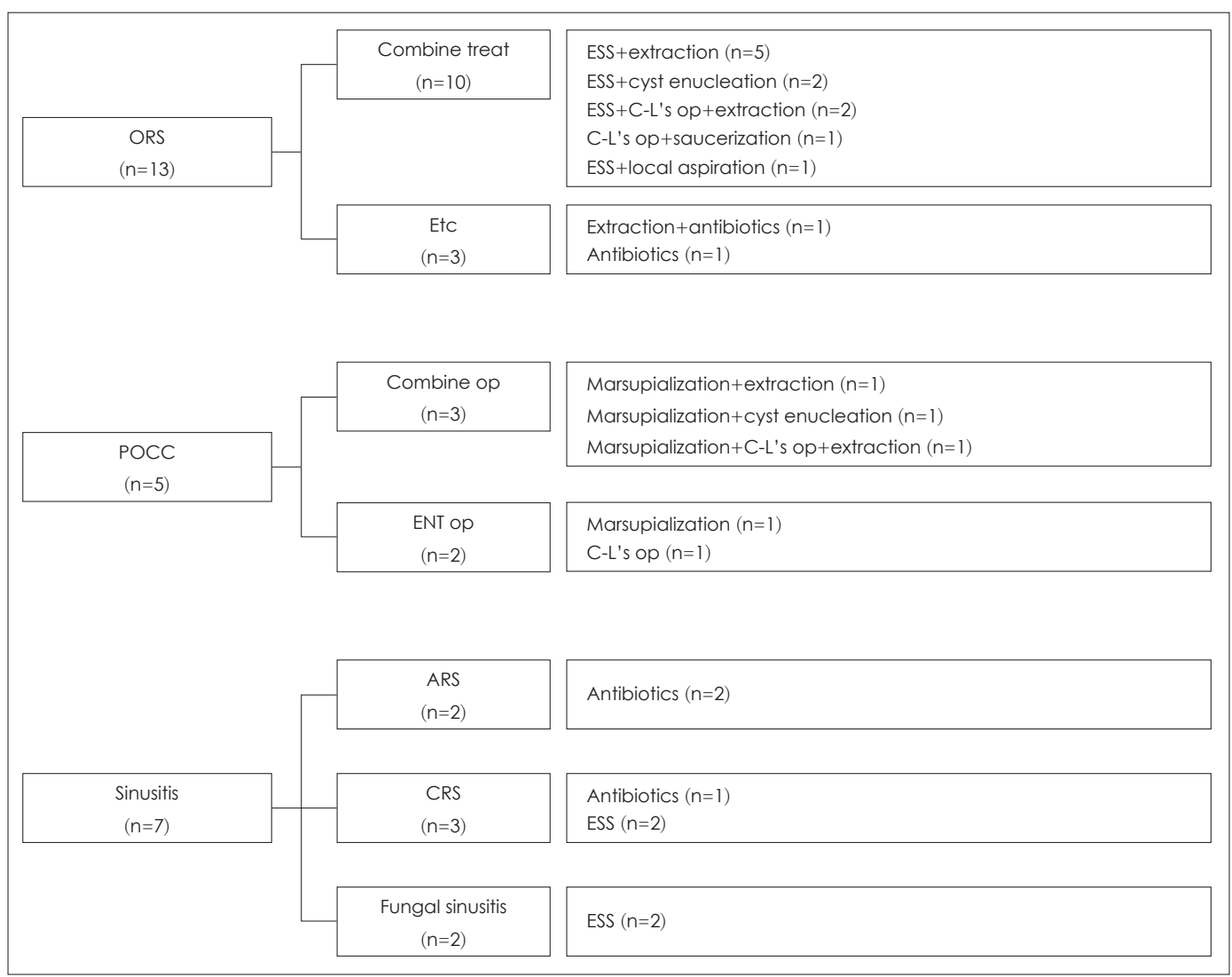

Fig. 3. Treatment of maxillary disease. POCC: postoperative cheek cyst, ORS: odontogenic rhinosinusitis, C-L: Caldwell-Luc, ESS: endoscopic sinus surgery, op: operation, ENT: department of otorhinolaryngology.

치성 상악동염의 치료는 상악동 및 치아 쪽 치료 같이 진행 한 경우가 11 건, 발치만 진행한 경우 1 건, 항생제 사용 후 증 상 호전된 경우 1 건 있었다. 수술적 치료는 내시경 부비동 수 술(endoscopic sinus surgery) 및 발치 4건, 내시경 부비동 수 술 및 낭종 제거술(cyst enucleation) 2건, 내시경 부비동 수 술 및 상악동근치수술(Caldwell-Luc's operation) 및 발치 2건, 상악동근치수술 및 치근단소파술 1 건, 내시경 부비동 수 술 및 점막 흡인 1건이었다. 모든 치료에서 재발 소견은 없었다.

나머지 상악동염의 치료는 급성 부비동염에서 항생제 사용 2 건, 만성 부비동염에서 내시경 부비동 수술 2 건, 항생제 사용 1 건이 있으며, 진균성 부비동염에서 내시경 부비동 수술 2건 이 있었고 모두에서 재발 소견은 없었다.

수술 후 협부낭종은 5건이 있었으며, 전산화단층촬영하 협 부낭종으로 인해 치아 및 치근단 파급의심하에 치과와 협진 하였다. 증상은 상악동 동통 2건, 협부 부종 2건, 무증상 1 건 이었으며, 치료는 조대술(marsupialization) 및 발치 2건, 조 대술 및 낭종 제거술 1 건, 조대술 단독 치료 2건이었다. 1건에 서 협부낭종 재발 및 협부농양이 발생하였다. 질환 별 치료에 대해서는 Fig. 3으로 정리하였다.

치근낭은 2건이 있었으며, 치근낭에 의한 치성 부비동염 의
심 하 협진하였으며, 2건 모두 낭종 제거술 및 항생제를 사용 하였고 재발은 없었다.

\section{고 찰}

이비인후과에 내원한 상악동 질환 환자에서 치과와의 협진 은 크게 3가지 이유로 분류할 수 있다. 첫번째는 치아 및 치주 질환이 상악동에 파급되어 발생하는 상악동 질환으로 협진 하 진단 및 치료가 필요한 경우이고, 두번째는 상악동에 생긴 질환이 치과와 연관성이 있는지 확인하는 경우, 세번째는 영 상검사상 치과적 질환이 확인되어 치과의 치료가 필요한 경 우이다. 이는 해부학적으로 상악동과 치근 사이의 거리가 가 깝고 영향을 받기 쉽기 때문이다.

발생학적으로 상악동은 태아 3주에서부터 자라기 시작하 며 14 16세에 이를 때까지 자란다.) 완전히 자라지 않은 상 악동은 상악동 치아의 뿌리와 떨어져 있지만, 상악동이 함기 화 되어 충분히 넓어진 이후에는 상악동 바닥이 상악동의 소 구치와 대구치에 맞닿게 되며, 제 2 대구치가 가장 가깝다. 치 근단과 상악동의 최단거리는 $1.97 \mathrm{~mm}$ 로 매우 가까워 지며, 이는 곧 상악동이 치아에 영향을 받을 수 있는 근거가 된다. ${ }^{2)}$ 
치과와 협진이 필요한 상악동 질환은 염증성 질환과 비염 증성 질환으로 분류가 가능하며, 염증성 질환에는 치성 부비 동염이 가장 대표적이며, 치근낭, 임플란트 관련 부비동염, 구 강상악동루 등이 있다. 비염증성 질환은 구강악안면의 다양 한 양성 및 악성종양을 의미하며, 대부분 양성종양이지만 악 성을 염두에 둘 필요가 있다.

치성 부비동염은 전체 부비동염의 $10 \%$ 정도를 차지한다고 알려져 있으며, 논문에 따라 $40 \%$ 까지 알려진 경우도 있는 정 도로 부비동염의 주요 원인이 될 수 있다. ${ }^{3)}$ 2012년 European position paper on rhinosinusitis and NPs(EPOS)에서 만성 부비동염의 원인으로 치성 부비동염의 가능성을 처음 언급하 였으나, 이후에도 만성 부비동염의 진단에 있어서 크게 고려 되지는 않았다. ${ }^{4.5}$ Ly와 Hellgren ${ }^{6}$ 의 연구에서 치성 부비동염 환자의 $1 / 3$ 정도는 치과적 원인을 감별하는 진료를 하지 않 았다고 하였다. 높은 유병률에도 불구하고 이비인후과 의사 들의 진단에서 치과적 원인을 간과하는 경우가 많다.

치성 부비동염을 일으키는 원인은 여러가지가 존재한다. 가 장 흔한 원인으로는 충치나 치근염, 치아주위농양 등에 의한 치아 및 치근단의 감염으로 인한 치성 부비동염이다.) 치성 낭 종이나 함치성 낭종 등 낭성 질환 역시 치성 부비동염을 야기 할 수 있다. ${ }^{2)}$ 치과치료에 의한 치성 부비동염에서는 가장 흔 한 경우는 발치이고 다른 치근단 치료, 상악동 골절술(osteotomy) 역시 치성 부비동염을 야기하기도 한다. 임플란트에 의 한 치성 부비동염의 발생도 존재하며, 상악동 거상술(sinus lift)이나 임플란트의 염증반응으로 치성 상악동염이 발생한 다. 마지막으로 상악동 외상 등에 의해서도 치성 부비동염이 발생할 수 있다.) 임플란트가 개발 된 이후 임플란트에 의한 치 성 부비동염의 발생 빈도는 증가하는 양상이다. ${ }^{8)}$ 본 연구에서 는 발치, 치주염에 의한 치성 부비동염이 각각 4명씩으로 가장 많은 수를 차지하였으며, 이는 상악동염이 있는 환자 중에 발 치, 치주염 여부를 파악해야하는 근거가 된다. Pokorny와 $\mathrm{Ta}-$ $\operatorname{taryn}^{9}$ 에 의하면 치성 부비동염의 4대 주 증상은 안면통(88\%), 후비루(64\%), 비충혈(45\%), 상악동 치통(39\%)순으로 나타난 다고 하며, 본 연구에서 후비루(30\%), 안면통(30\%)이 대부분 의 증상을 차지하였고 치통을 호소하는 환자는 많지 않았다.

진단에 있어 CT가 gold standard이다.) 영상의학적 평가로 는 X-ray보다는 CT가 상악동 질환의 감별에 도움이 되며, 치 성 부비동염의 $70 \%$ 정도는 paranasal sinus CT(PNS CT)로 평가가 가능하다. ${ }^{10,11)}$ 치과에서는 기본적으로 panoramic radiography를 이용하며, 상악동 치아의 탈구, 치근과 치아의 상태, 가성 낭종, 이물질 등을 파악할 수 있다. ${ }^{9)} \mathrm{CBCT}$ 역시 진단에 도움이 되는 데, 일반적인 CT에 비해 방사선 피폭량이 $1 / 10$ 이면서, 뼈의 구조를 자세히 알 수 있고, 치아 구조에 대한
3 차원적인 이해가 가능하다. ${ }^{12}$ 하지만 Longhini와 Ferguson ${ }^{5)}$ 의 연구에 따르면, 치아 감염이 있더라도 초기 CT상 $67 \%$, panoramic radiography에서 86\%에서 위 음성이 나타난다고 한 다. 그러므로 초기 CT상 치성 부비동염이 진단되지 않더라도 문진을 통해 최근의 발치, 치과 치료 과거력, 상악동의 골절 및 외상, 치료 후 재발하는 편측의 상악동 질환이 있다면 치과 진 료를 권유해야 한다.7.13)

본 연구에서도 PNS CT를 통한 치성 부비동염의 진단이 얼 마나 의미 있는지를 확인하였다. CT와 실제 진단을 비교하였 을 때 CT상 양성 소견이 나온 11 명 중 10 명이 실제 치성 부비 동염으로 진단되었고, CT상 음성 소견이 나온 9명 중, 6명이 실제로 치성 부비동염이 없었다. 이를 보았을 때 CT상 이상소 견이 보이지 않더라도, 발치 및 치과치료 과거력이나, 치통이 나 상악동 동통 등의 문진을 통한 정보로 치성 부비동염을 감별해야함을 의미한다. 다만 본 연구에서 봤을 때 최근의 치 과치료, 발치 등이 없이 치통이나 안면통을 호소하는 환자에 서 치성 부비동염이 진단되지 않았다. 증상은 환자가 주관적 으로 호소하기 때문에 증상보다는 치과치료 과거력이 더 유 의미한 진단의 근거가 된다.

상악동 질환을 가진 환자의 치료는 기본적으로 병소의 적 절한 처치와 재발의 방지이다. 치성 부비동염은 치성 감염원 의 외과적인 제거와 부비동염의 치료가 같이 이루어져아 한 다. ${ }^{8)}$ 부비동염의 치료는 수술적 치료가 가장 중요하며, 치성 부비동염은 항생제가 잘 듣지 않는다. 치성 부비동염은 일반 적인 Streptococcus pneumoniae, Haemophilus influenzae, Moraxella catarrhalis 등의 균주와 더불어 구인두에서 발견 되는 혐기성 균주와 그람 음성균도 발견되므로 항생제로 치 료가 어렵다. ${ }^{14)}$ 수술적 치료는 내시경적 부비동 수술과 치성 감염원의 제거이다. 대부분의 경우 내시경 부비동 수술로 병 변의 제거가 가능하며, 상악동근치수술은 술후 협부낭종 및 합병증의 위험성이 높아 추천되지 않는다. 치과에서는 치아 및 치근단의 상태에 따라, 치근염일 경우 소독 혹은 발치, 심 할 경우 상악동근치수술이 동반되며, 치근낭이 원인일 경우 낭종 적출술, 골수염까지 발생한 경우 소파술을 시행할 수 있 다. 본 연구에서도 1 건을 제외하고는 모두 치아의 수술적 치 료를 시행하였다. 과거에 비해 구강 위생 상태의 호전과 치과 의 접근성 및 치아 치료가 빈번하게 이루어짐에도 과거에 비 해 치성 부비동염의 유병률은 비슷하다. 임플란트와 같은 침 습적인 치아 시술의 빈도가 증가하는 것이 한 원인이 될 수 있 고, $\mathrm{CBCT}$ 등 영상 검사의 처방이 늘어나면서, 영상 검사상 우 연히 발견하게 되는 부비동염의 빈도수가 늘어나 ${ }^{15)}$ 이비인후 과 및 치과의 협진을 통해 치성 부비동염의 조기 검진률이 올 라갔다고 생각한다. 
본 연구에서 4년간의 치과와 협진 하에 치료한 환자들의 자 료를 보았을 때, 대부분의 경우 치성 부비동염을 진단 및 치료 하기 위해 협진하였으며, 수술 후 협부낭종의 치아 및 상악동 의 접근하는 경우도 많음을 알 수 있었다.

치성 부비동염을 진단하기 위해서는 치과와의 협진이 필수 적인데, 본 연구에서는 치통, 안면통, 악취와 같은 증상으로 의심한 환자들은 모두 치성 부비동염으로 진단되지 않았다. 이는 환자의 증상만으로 진단의 근거로 삼기에는 어렵다고 생 각된다. 하지만 표본 수가 적어 추가적인 연구가 더 필요하다 고 생각된다.

이에 비해 최근의 발치, 치주염, 치근단 치료를 받은 환자들 16 명 중 11 명(68\%)이 치성 부비동염으로 진단되었다. 이러한 과거력은 치성 부비동염을 의심하기에 좋은 근거가 될 것으로 보이며, 이비인후과 진료 시 치과 과거력을 필수적으로 물어 보아야 한다.

이비인후과의사에서 치성 원인을 감별하기 위해 부비동 전 산화단층촬영이 진단의 도구로 많이 사용된다. 하지만 본 연 구에서와 같이 $23 \%$ 정도 전산화단층촬영에서 음성이 나와도 치성 부비동염으로 진단되는 경우가 있어, 치과치료 과거력, 특 히 최근의 발치나 치주염으로 치료한 과거력이 있고 증상 발현 과 시간적 순서가 맞을 시에는 치과 진료를 권유하는 것이 바 람직하다.

결론적으로, 저자들은 본 연구를 통해 상악동 질환을 가진 환자가 내원했을 경우 편측 상악동 질환을 가지며, 치과 치료 과거력이 있고, 상악동 질환의 발현과 시간적 순서가 맞거나, 전산화단층촬영상 의미있는 소견이 있을 때 치과와 협진이 필 요하며, 일부의 경우 전산화단층촬영상 음성소견이 있는 환 자들이 있어, 이학적 검사와 문진을 통해 치아의 문제가 의심 된다면 적극적인 협진을 통해 치성 부비동염을 진단해야 할 필요가 있을 것으로 사료된다. 또한 본 연구는 치성 부비동염 을 진단하는 과정에서 치성 부비동염 환자의 특성을 분석하 는데 도움이 될 것으로 생각되며 추가적인 연구를 통해 명확 한 진단 기준이 정립할 필요가 있을 것으로 사료된다.

\section{Acknowledgments}

This work was supported by the Dong-A University research fund.

\section{Author Contribution}

Conceptualization: Woo Yong Bae. Data curation: Daeyeon Kim. Formal analysis: Daeyeon Kim. Investigation: Sang Hoo Park. Methodology: Sang Hoo Park. Supervision: Woo Yong Bae. Writing — original draft: Sangjun Kim. Writing — review \& editing: Woo Yong Bae.

\section{ORCIDs}

Woo Yong Bae https://orcid.org/0000-0001-5578-0225

Sangjun Kim https://orcid.org/0000-0002-6025-6775

Daeyeon Kim https://orcid.org/0000-0002-1693-5981

Sang Hoo Park https://orcid.org/0000-0002-5994-2428

\section{REFERENCES}

1) Mehra P, Murad H. Maxillary sinus disease of odontogenic origin. Otolaryngol Clin North Am 2004;37(2):347-64.

2) Brook I. Sinusitis of odontogenic origin. Otolaryngol Head Neck Surg 2006;135(3):349-55.

3) Workman AD, Granquist EJ, Adappa ND. Odontogenic sinusitis: Developments in diagnosis, microbiology, and treatment. Curr Opin Otolaryngol Head Neck Surg 2018;26(1):27-33.

4) Fokkens WJ, Lund VJ, Mullol J, Bachert C, Alobid I, Baroody F, et al. EPOS 2012: European position paper on rhinosinusitis and nasal polyps 2012. A summary for otorhinolaryngologists. Rhinology 2012;50(1):1-12.

5) Longhini $A B$, Ferguson BJ. Clinical aspects of odontogenic maxillary sinusitis: A case series. Int Forum Allergy Rhinol 2011;1(5):409-15.

6) Ly D, Hellgren J. Is dental evaluation considered in unilateral maxillary sinusitis? A retrospective case series. Acta Odontol Scand 2018;76(8):600-4.

7) Vidal F, Coutinho TM, Carvalho Ferreira D, Souza RC, Gonçalves LS. Odontogenic sinusitis: A comprehensive review. Acta Odontol Scand 2017;75(8):623-633.

8) Kim J, Kim SW, Cho JH, Kang JM, Kim BG, Kim JH, et al. Clinical manifestation of odontogenic sinusitis: As to pathophysiology and management. Korean J Otorhinolaryngol-Head Neck Surg 2009;52(7): 585-90.

9) Pokorny A, Tataryn R. Clinical and radiologic findings in a case series of maxillary sinusitis of dental origin. Int Forum Allergy Rhinol 2013;3(12):973-9.

10) Obayashi N, Ariji Y, Goto M, Izumi M, Naitoh M, Kurita K, et al. Spread of odontogenic infection originating in the maxillary teeth: Computerized tomographic assessment. Oral Surg Oral Med Oral Pathol Oral Radiol Endod 2004;98(2):223-31.

11) Troeltzsch M, Pache C, Troeltzsch M, Kaeppler G, Ehrenfeld M, Otto S, et al. Etiology and clinical characteristics of symptomatic unilateral maxillary sinusitis: A review of 174 cases. J Craniomaxillofac Surg 2015;43(8):1522-9.

12) Patel NA, Ferguson BJ. Odontogenic sinusitis: An ancient but underappreciated cause of maxillary sinusitis. Curr Opin Otolaryngol Head Neck Surg 2012;20(1):24-8.

13) Schulze D, Heiland M, Thurmann H, Adam G. Radiation exposure during midfacial imaging using 4- and 16-slice computed tomography, cone beam computed tomography systems and conventional radiography. Dentomaxillofac Radiol 2004;33(2):83-6.

14) Saibene AM, Vassena C, Pipolo C, Trimboli M, De Vecchi E, Felisati $\mathrm{G}$, et al. Odontogenic and rhinogenic chronic sinusitis: A modern microbiological comparison. Int Forum Allergy Rhinol 2016;6(1): 41-5.

15) Ahsan F, El-Hakim H, Ah-See KW. Unilateral opacification of paranasal sinus CT scans. Otolaryngol Head Neck Surg 2005;133(2): $178-80$. 